\title{
Erwinia carotovora has two KdgR-like proteins belonging to the IcIR family of transcriptional regulators: identification and characterization of the RexZ activator and the KdgR repressor of pathogenesis
}

\author{
Nicholas R. Thomson, ${ }^{1}$ William Nasser, ${ }^{2}$ Simon McGowan, ${ }^{1}$ \\ Mohammed Sebaihia ${ }^{1}$ and George P. C. Salmond ${ }^{1}$
}

\author{
Author for correspondence: George P. C. Salmond. Tel : +441223 333650. Fax: +441223333345. \\ e-mail: GPCS@mole.bio.cam.ac.uk
}

\footnotetext{
1 Department of Biochemistry, University of Cambridge, Tennis Court Road, Cambridge CB2 1QW, UK

2 Laboratoire de Génétique Moléculaire des Microorganismes et des Interactions Cellulaires, CNRS-UMR 5577, INSA Bat 406, 20 Avenue Albert Einstein, 69621 Villeurbanne Cedex, France
}

\begin{abstract}
A novel Erwinia carotovora subsp. carotovora mutant designated RexZ, (regulator of exoenzymes) showed reduced production of the degradative exoenzymes. The rexZ gene product shows similarity to the KdgR regulatory protein from Erwinia chrysanthemi, described as the major repressor of the pectin catabolism pathway genes in the latter species. In vitro DNA-protein interaction experiments demonstrated that the synthesis of the RexZ protein is controlled by the CAMP-CRP (CAMP-receptor protein) complex. Western blot analysis also revealed the presence of a second $\mathrm{KdgR}$ homologue (distinct from RexZ) which, like RexZ, was present in all species of the genus Erwinia tested. The corresponding KdgR proteins from both $E$. carotovora subsp. carotovora and $E$. carotovora subsp. atroseptica share a high level of sequence identity with the KdgR homologues from $E$. chrysanthemi and Escherichia coli. Although the $E$. carotovora subsp. carotovora rexZ regulatory region displayed specific interactions with both the purified $E$. chrysanthemi KdgR repressor and the partially purified E. carotovora subsp. carotovora KdgR, in vivo quantification revealed that the cellular level of RexZ protein was unaffected by the presence of pectic compounds. This study shows that the complex regulatory network governing virulence in the erwinias involves two totally distinct, but highly conserved, members of the IclR class of DNA binding proteins: RexZ and KdgR.
\end{abstract}

Keywords: phytopathogenicity, soft-rot, exoenzyme, transcriptional regulation

\section{INTRODUCTION}

The phytopathogenicity of several Erwinia species is correlated with the ability to produce and secrete plant cell wall degrading enzymes such as pectinases, cellulases (Cel) and proteases (Prt) (Collmer \& Keen, 1986; Barras et al., 1994). The crucial role of these enzymes, particularly the pectate lyases (Pel), in the

Abbreviations: CRP, cyclic AMP receptor protein; KDG, 2-keto-3-deoxygluconate; $\mathrm{OHHL}, \mathrm{N}$-(3-oxohexanoyl)-L-homoserine lactone; PGA, polygalacturonate.

The GenBank accession numbers for the sequences reported in this paper are given in the text. virulence of soft-rot Erwinia has been confirmed by the isolation of mutants exhibiting reduced virulence that are defective for production or secretion of these enzymes (Boccara et al., 1988; Hinton et al., 1989; Pirhonen et al., 1991). Exoenzyme production by softrot Erwinia species responds to several environmental conditions (Hugouvieux-Cotte-Pattat et al., 1996) : presence of pectin-degradative products or plant extract, anaerobiosis, temperature, nitrogen starvation, osmolarity, catabolite repression, iron availability and growth phase.

In Erwinia chrysanthemi 3937, attention has been focused on the pectin degradation pathway, and the different steps of this metabolic pathway have been 
characterized. The degradation of the pectic compounds is initiated by extracellular pectinases, including two pectin methylesterases (encoded by pemA and pemB) (Laurent et al., 1993; Shevchik et al., 1996), five major isoenzymes of pectate lyases (encoded by pelA, pelB, pelC, pelD and pelE) and a set of secondary pectate lyases (Hugouvieux-Cotte-Pattat et al., 1996) which generate unsaturated digalacturonate. These latter compounds are transported into the bacterium, where they are catabolized by the products of the genes $o g l, k d u I$, $k d u D, k d g K$ and $k d g A$ (Condemine et al., 1986; Hugouvieux-Cotte-Pattat \& Robert-Baudouy, 1987; Reverchon \& Robert-Baudouy, 1987). It has been demonstrated that the full expression of the pectin catabolism genes in E. chrysanthemi 3937 requires the presence of the cAMP-CRP (cAMP-receptor protein) complex (Reverchon et al., 1997; Nasser et al., 1997) and that the KdgR repressor essentially mediates the induction of this catabolic pathway in response to pectic compounds (Reverchon et al., 1991). In vitro experiments showed that the specific binding of the KdgR repressor to the operators of genes it regulates is inhibited in the presence of the pectin catabolic product 2-keto-3-deoxygluconate (KDG). Thus, it was proposed that KDG is the real intracellular inducer of the pectinolysis genes (Nasser et al., 1991, 1994). In addition to $k d g R$, two other loci that negatively regulate the expression of the pectinase genes, pecS-pecM and pecT, have also been characterized in E. chrysanthemi. However, the signal to which they respond remains unknown (Reverchon et al., 1994; Praillet et al., 1996; Surgey et al., 1996; Castillo \& Reverchon, 1997).

In the related soft-rot species, Erwinia carotovora subsp. carotovora, analysis of regulatory mutants has allowed the identification of several loci involved in the regulation of exoenzyme genes: expl/carl/bsll, hor, aepA, aepH $(r s m B), r s m A$ and hexA. The gene expl/carl/hsll, a homologue of the Vibrio fischeri luxI gene, directs the production of an autoinducer molecule identical to the one synthesized by LuxI and called $\mathrm{N}$-(3-oxohexanoyl)L-homoserine lactone (OHHL) (Jones et al., 1993; Pirhonen et al., 1993; Salmond et al., 1995; Chatterjee et al., 1995). OHHL regulates the synthesis of Pel, polygalacturonase (Peh), Cel and Prt and the production of the antibiotic carbapenem in E. carotovora subsp. carotovora (Jones et al., 1993; Pirhonen et al., 1993). Similarly, the Hor protein has also been found to regulate exoenzyme and antibiotic production in $E$. carotovora (Thomson et al., 1997). Mutations in the genes aepA and aepH $(r s m B)$ have been shown to affect extracellular enzyme synthesis (Murata et al., 1991; Liu et al., 1993). AepA activates the transcription of pel-1, which encodes the major Pel in E. carotovora subsp. carotovora strain 71 (Liu et al., 1993; Murata et al., 1994), and the RNA transcript of aepH (rsmB) activates the synthesis of Pel, Peh, Cel and Prt by way of its interaction with RsmA (Liu et al., 1998). The negative regulatory gene, $r s m A$, when carried on a multicopy plasmid has been shown to suppress the production of the depolymerizing enzymes, the synthesis of OHHL and the extent of plant pathogenicity in several softrotting Erwinia spp. (Cui et al., 1995). Although the number of regulatory inputs governing exoenzyme production is extensive, few regulators common to both E. chrysanthemi and E. carotovora have been described to date. Even where a common regulator has been reported, such as HexA (E. carotovora)/PecT (E. chrysanthemi), its regulatory effects are not the same in both species (Harris et al., 1998).

In this paper, we describe the identification, cloning and characterization of an E. carotovora regulatory gene, rexZ, the product of which displays homology with the E. chrysanthemi KdgR repressor protein. However, unlike KdgR, RexZ acts as an activator of exoenzyme production and therefore virulence. We describe the construction of an $E$. carotovora rex $Z$ mutant by reverse genetics and the analysis of the $E$. carotovora rex $Z$ mutant phenotype with respect to synthesis of depolymerizing enzymes. In addition, the modulation of RexZ protein synthesis, in E. carotovora, was also investigated. This study also shows that E. carotovora contains a homologue of the E. chrysanthem $i \mathrm{KdgR}$ in addition to the novel RexZ protein; both are members of the IclR class of DNA-binding proteins. Furthermore, sequence analysis of $\mathrm{KdgR}$ homologues, isolated from E. carotovora subsp. carotovora and E. carotovora subsp. atroseptica, showed that the $\mathrm{N}$-terminus of these proteins is different from that previously reported for the $E$. chrysanthemi KdgR protein, but agreed well with the Escherichia coli KdgR protein sequence. Finally, the functional interchangeability of the E. carotovora subsp. carotovora and E. chrysanthemi $\mathrm{KdgR}$ virulence repressors was investigated.

\section{METHODS}

Bacterial strains, plasmids and culture conditions. Bacterial strains and plasmids are described in Table 1. Erwinia spp. and Escherichia coli were grown at $30^{\circ} \mathrm{C}$ and $37^{\circ} \mathrm{C}$ respectively, in LB medium or M63 minimal medium (Miller, 1972) supplemented with a carbon source $(0.2 \%$, except PGA and pectin, $0.4 \%$ ) and, when required, with amino acids $\left(40 \mu \mathrm{g} \mathrm{ml}^{-1}\right)$. Antibiotics were used at the following final concentrations: streptomycin (Sm) and ampicillin (Ap), $100 \mu \mathrm{g} \mathrm{ml}^{-1}$; kanamycin $(\mathrm{Km})$ and chloramphenicol $(\mathrm{Cm})$, $50 \mu \mathrm{g} \mathrm{ml}^{-1}$; tetracycline (Tc), $20 \mu \mathrm{g} \mathrm{ml}^{-1}$.

Exoenzyme liquid and plate assays. Pectinase and cellulase activities were detected using plate assays as described by Andro et al. (1984). Protease activity was determined using the plate assay of Hankin \& Anagnostakis (1975). Samples of overnight culture to be tested were spotted onto the appropriate enzyme assay plate and incubated at $30^{\circ} \mathrm{C}$ for $24 \mathrm{~h}$. Liquid enzyme assays of cellulase and protease activity were performed as described previously (Hinton \& Salmond, 1987). Total specific activity, expressed as $\Delta A_{550} \mathrm{mg}^{-1} \mathrm{~min}^{-1} \mathrm{ml}^{-1}$ and $\Delta A_{436} \mathrm{mg}^{-1} \mathrm{~min}^{-1} \mathrm{ml}^{-1}$, for cellulase and protease respectively, was determined. Liquid assays of pectate lyase activity were performed on toluenized cell extracts as described previously (Moran et al., 1968).

Recombinant DNA techniques. All molecular biological techniques have been described previously (Ausubel et al., 1987), unless otherwise stated. Nucleotide sequence analysis of rexZ 
was performed by the chain-termination method (Sanger et al., 1977) on random sonicated templates cloned into the M13 vector mp18 or mp19. PCR (using Taq DNA polymerase, NEB; annealing temperature $43^{\circ} \mathrm{C}$ ) was used to amplify the $E$. carotovora subsp. carotovora SCRI193 rexZ gene, using primers EcK1 (CGGGATCCGTTGCGTTATTATTG) and Eck2 (GGTCTAGAAGCAGATGGAGTATTGG), from chromosomal DNA. PCR (using Taq DNA polymerase, NEB; annealing temperature $42^{\circ} \mathrm{C}$ ) was also used to amplify an $E$. chrysanthemi $k d g R$-specific gene probe using primers EHR 1 (ATGGATGATATTAATCGG) and EHR2 (ACGGATAATCGTGGTATC) complementary to the terminal $5^{\prime}$ and $3^{\prime}$ sequences of the $k d g R$ ORF, respectively. For Southern blots the $k d g R$-specific gene probe was labelled using the 'nonradioactive' DIG-11-dUTP kit (Boehringer Mannheim).

The E. carotovora subsp. carotovora SCRI193 mini-library was constructed in pACYC184 (Chang \& Cohen, 1978). Chromosomal DNA was prepared and digested with EcoRV, before being size-fractionated by agarose gel electrophoresis. Size-fractionated DNA of between $4 \mathrm{~kb}$ and $7.5 \mathrm{~kb}$ was recovered from the agarose gel using a Geneclean Kit (BIO 101) and ligated into pACYC184, also digested with EcoRV. The ligated products were used to transform Escherichia coli DH1 by electroporation. Transformants were selected on nutrient media supplemented with $\mathrm{Cm}$. The $k d g R$ gene homologue of E. carotovora subsp. carotovora SCRI193 was sequenced using universal forward and reverse M13 primers (Pharmacia). Additional primers were designed to complete the sequencing: KD1 (GCTCAGGCATTGATAGGG), KD3 (CACATTTTATGGCGCGG) and KD5 (CGGGATCCTGTGGACTATCTTACC). The $k d g R$ gene homologues from $E$. carotovora subsp. carotovora strains $\mathrm{F} 14$ and $\mathrm{F} 148$, and $E$. carotovora subsp. atroseptica strain SCRI27, were sequenced using the pBluescript primers T3 and T7 (Stratagene). The nucleotide sequence of the $k d g R$ homologues reported in this study was generated on an Applied Biosystems 373 automated sequencing machine using Taq FS (Perkin-Elmer). Nucleotide sequence data were analysed using the MAC MOLLY TETRA program (SoftGene, Berlin) or on BLAST, searching the GenBank/EMBL and SWISS-PROT databases.

Marker-exchange mutagenesis of the rexZ gene. A $2 \cdot 8 \mathrm{~kb}$ $B a m H I$ fragment of pMO11, carrying $\operatorname{rexZ}$, was cloned in pKNG101 (Kaniga et al., 1991) also digested with BamHI, to yield pSMG38. The rexZ gene was insertionally inactivated by the cloning of a 1266 bp NlaIV fragment of pACYC177 (Chang \& Cohen, 1978), encoding resistance to kanamycin, into pSMG38 at the unique Scal site. The resulting plasmid, pSMG39, was used to marker-exchange E. carotovora subsp. carotovora ATTn10 as previously described (Kaniga et al., 1991).

Purification of the E. carotovora subsp. carotovora KdgR protein for $\mathrm{N}$-terminal sequencing. Using the pUC19 -48 reverse oligonucleotide primer (NEB) and primer KD6 (CCCAAGCTTCAGTGATGGTGATGGTGATGGAAAGGGTAATCGTGGTAGC) the E. carotovora subsp. carotovora $k d g R$ gene was amplified by PCR from plasmid $\mathrm{pREP} 4$. Primer KD6 was designed such that six codons encoding histidine residues were incorporated into the $3^{\prime}$ end of the $k d g R$ ORF. The resultant amplified PCR product was digested with HindIII and ligated into pUC19, digested with the same enzyme, and used to transform Escherichia coli DH1. Transformants were selected on nutrient media supplemented with Ap. The KdgR-His tagged protein was purified from cultures grown to early stationary phase using Ni-NTA resin (Qiagen) as described in the manufacturer's instructions. Purified protein, after SDS-PAGE, was blotted on to PVDF membrane (Boehringer Mannheim) and visualized using Ponceau-S stain (Sigma). $\mathrm{N}$-terminal sequencing was performed on an Applied Biosystems automated peptide sequencer.

Preparation of $E$. carotovora subsp. carotovora cell extract for gel retardation assays. Cells from a 1 litre culture of $E$. carotovora subsp. carotovora SCRI193 were pelleted, washed and resuspended in $50 \mathrm{ml}$ extraction buffer $(10 \mathrm{mM}$ HEPES/NaOH pH 7.9, $4 \mathrm{mM}$ Tris/ $\mathrm{HCl}$ pH 7.9, $1 \mathrm{mM}$ EDTA, 5\% glycerol, $1 \mathrm{mM}$ PMSF, $1 \mathrm{mM}$ DTT). Crude protein extract was obtained by disrupting bacteria at $13.8 \mathrm{MPa}$ in a French press (AMINCO). Crude extract was then centrifuged to remove cell debris and the supernatant was submitted to fractionated precipitation with ammonium sulphate using: $0-20,20-40,40-70$ and $70-100 \%$ saturation. The precipitated protein fractions were resuspended in a small volume of extraction buffer and dialysed against the same buffer to remove any residual ammonium sulphate. The $20-40 \%$ ammonium sulphate saturation protein fraction was identified, by Western blot analysis, as containing KdgR. This fraction constituted the partially purified $\mathrm{KdgR}$ fraction used for band-shift assays.

Preparation of operator fragments for binding studies. The regulatory regions of rex $Z$ and the E. chrysanthemi pelE genes were cloned into pBluescript (Table 1) and end-labelled as previously described (Nasser et al., 1997). These labelled fragments were further purified with the Qiagen quick extraction kit.

Gel retardation assays and footprinting with DNase I. These assays were performed as previously described (Nasser et al., 1997). Gel retardation assays were conducted using various amounts of either crude protein extract $(2-20 \mu \mathrm{g})$ or purified CRP or KdgR protein.

Production of RexZ in Escherichia coli and generation of RexZ-specific antibodies. The rexZ ORF was amplified by $P C R$ using primers which introduced a unique $N d e$ I restriction site at the ATG initiation codon and an EcoRI site after the stop codon. By cloning the $798 \mathrm{bp}$ amplified NdeI-EcoRI fragment into the $\mathrm{pT} 7-7$ vector, to yield $\mathrm{pWS} 2$, the rexZ ATG start codon was fused to the T7 promoter. Expression of rexZ was performed using the methods described by Tabor $\&$ Richardson (1985). Crude protein extract was obtained by disrupting bacteria at $13.8 \mathrm{MPa}$ in a French pressure cell (AMINCO). Cell debris and insoluble material was recovered by centrifugation at $20000 \mathrm{~g}$ for $20 \mathrm{~min}$. The expressed RexZ protein contained within the resultant pellet was further purified by preparative SDS-PAGE. Gel fragments containing RexZ were excised, crushed, suspended in phosphate-buffered saline (10 mM Na $2 \mathrm{HPO}_{4}, 1.76 \mathrm{mM} \mathrm{KH}_{2} \mathrm{PO}_{4}, 138 \mathrm{mM} \mathrm{NaCl}$, $2.7 \mathrm{mM} \mathrm{KCl}$ ) and injected subcutaneously into a New Zealand White rabbit. KdgR-specific antibodies were also generated, in a similar manner, using purified KdgR protein (Nasser et al., 1992). The anti-RexZ and anti-KdgR antibodies were purified from rabbit antisera, as previously described (Praillet et al., 1996; Sakakibara et al., 1991). The recovered antisera reacted specifically with either RexZ or KdgR.

Immunoblotting. After separation on a $12 \%$ SDS-PAGE gel, proteins were electrotransferred onto a Hybond-C membrane using a 1017 Macrophor system (Pharmacia LKB). The membranes were washed and challenged with anti-RexZ or anti-KdgR antibodies diluted to $1 / 200$ and $1 / 500$, respectively, 
Table 1. Bacterial strains and plasmids

\begin{tabular}{|c|c|c|}
\hline Strain & Genotype or description* & Source or reference \\
\hline \multicolumn{3}{|c|}{ Escherichia coli } \\
\hline NM522 & $\begin{array}{l}\Delta(\text { lac-pro } A B) \text { thi hsd5 supE }\left[\mathrm{F}^{\prime} \text { pro } A B^{+}\right. \\
\left.\text {lacI }{ }^{\mathrm{l}} \text { lac } \mathrm{Z} \Delta \mathrm{M} 15\right]\end{array}$ & Stratagene \\
\hline $\mathrm{K} 38$ & $\mathrm{HfrC}(\lambda)$ phoA4 pit-10 tonA22 ompF627 relA1 & Russel \& Model (1984) \\
\hline $\mathrm{DH} 1$ & $\begin{array}{l}\mathrm{F}^{-} \text {recA1 endA1 thi-1 hsdR17 gyrA96 }\left(\mathrm{r}_{\mathrm{k}}^{-} \mathrm{m}_{\mathrm{k}}^{-}\right) \text {supE44 } \\
\quad \text { relA1 }\end{array}$ & Hanahan (1983) \\
\hline CC118 & $\begin{array}{l}\Delta(\text { ara-leu }) \text { araD } \Delta l a c X 74 \text { galE galK phoA20 thi-1 rpsE } \\
\text { rpoB argE }(\mathrm{am}) \text { recA1 }\end{array}$ & Herrero et al. (1990) \\
\hline CC118(גpir) & As CC118, lysogenised with $\lambda$ pir phage & Herrero et al: (1990) \\
\hline \multicolumn{3}{|l|}{ Erwinia spp. } \\
\hline \multicolumn{3}{|c|}{ Erwinia chrysanthemi } \\
\hline 3937 & Wild-type strain isolated from Saintpaulia ionanthia & Kotoujansky et al. (1982) \\
\hline A903 & $\operatorname{lm} r T^{\mathrm{c}} \operatorname{lac} Z 2 k d g R:: \operatorname{Tn} 5$ & Condemine \& Robert-Baudouy (1987) \\
\hline EC16 & Wild-type & A. Chatterjee, Univ. of Missouri \\
\hline \multicolumn{3}{|c|}{$\begin{array}{l}\text { E. carotovora subsp. } \\
\text { carotovora }\end{array}$} \\
\hline SCRI193 & Wild-type & Hinton \& Salmond (1987) \\
\hline ATTn10 & Wild-type, restrictionless & McGowan et al. (1996) \\
\hline SM2 & ATTn10, rexZ::kan & This study \\
\hline PNP22 & ATTn10, $\mathrm{Carl}^{-}$ & McGowan et al. (1995) \\
\hline F14 & Wild-type & General lab stock \\
\hline F148 & Wild-type & General lab stock \\
\hline \multicolumn{3}{|c|}{$\begin{array}{l}\text { E. carotovora subsp. } \\
\text { atroseptica }\end{array}$} \\
\hline SCRI31 & Wild-type & Hinton et al. (1985) \\
\hline SCRI27 & Wild-type & $\begin{array}{l}\text { M. Perombelon, Scottish Crop Research } \\
\text { Institute }\end{array}$ \\
\hline \multicolumn{3}{|l|}{ E. amylovora } \\
\hline SCRI449 & Wild-type & $\begin{array}{l}\text { M. Perombelon, Scottish Crop Research } \\
\text { Institute }\end{array}$ \\
\hline \multicolumn{3}{|l|}{ E. berbicola } \\
\hline SCRI424 & Wild-type & $\begin{array}{l}\text { M. Perombelon, Scottish Crop Research } \\
\text { Institute }\end{array}$ \\
\hline \multicolumn{3}{|l|}{ Plasmids } \\
\hline pUC19 & Cloning vector, $\mathrm{Ap}^{\mathrm{r}} \operatorname{lac} Z^{\prime}$ & Yanisch-Perron et al. (1985) \\
\hline cWU142 & $\begin{array}{l}\text { pSF6 harbouring the carbapenem biosynthetic cluster, } \\
k d u I, k d g T \text { and } \operatorname{rex} Z\end{array}$ & McGowan et al. (1995) \\
\hline pMO11 & $\begin{array}{l}\text { pUC19 derivative harbouring rexZ of E. carotovora } \\
\text { subsp. carotovora ATTn10 }\end{array}$ & McGowan et al. (1997) \\
\hline pBluescript & $A^{r} \operatorname{lac}^{\prime}$ & Stratagene \\
\hline pSR 1175 & $\begin{array}{l}\text { pBluescript harbouring the pelE regulatory region of } \\
\text { E. chrysanthemi } 3937\end{array}$ & Nasser et al. (1994) \\
\hline $\mathrm{pW}$ W1 & $\begin{array}{l}\mathrm{pBluescript} \text { harbouring the rex } \mathrm{Z} \text { regulatory region of } \\
\text { E. carotovora subsp. carotovora ATTn } 10\end{array}$ & This work \\
\hline pACYC177 & Cloning vector, $\mathrm{Ap}^{\mathrm{r}} \mathrm{Kn}^{\mathrm{r}}$ & Chang \& Cohen $(1978)$ \\
\hline pKNG101 & $s a c B$ marker-exchange vector, $\mathrm{Str}^{\mathbf{r}}$ & Kaniga et al. (1991) \\
\hline pSMG38 & $\begin{array}{l}\text { pKNG101 derivative harbouring rexZ of E. carotovora } \\
\text { subsp. carotovora ATTn10 }\end{array}$ & This work \\
\hline pSMG39 & pKNG101 derivative harbouring rexZ::kan insertion & This work \\
\hline $\mathrm{pT} 7-7$ & $A p^{r}$ & Tabor \& Richardson (1985) \\
\hline pWS2 & pT7-7 harbouring the coding region of $\operatorname{rexZ}$ & This work \\
\hline pULB113 & $\mathrm{RP} 4:: \mathrm{Mu} 3 \mathrm{~A}$ & Van Gijsegem \& Toussaint (1982) \\
\hline pROU2 & $\begin{array}{l}\text { pULB113 derivative harbouring } k d u D, k d g R \text { and } o g l \\
\text { genes of E. chrysantbemi } 3937\end{array}$ & Reverchon \& Robert-Baudouy (1987) \\
\hline
\end{tabular}


Table 1 (cont.)

\begin{tabular}{|c|c|c|}
\hline Strain & Genotype or description* & Source or reference \\
\hline pREP1 & $\begin{array}{l}\text { pACYC184 harbouring the E. carotovora subsp. } \\
\text { carotovora SCRI193 kdgR }\end{array}$ & This work \\
\hline pREP4 & $\begin{array}{l}\text { pUC19 harbouring a } 2 \cdot 1 \mathrm{~kb} \text { EcoRV-SpbI subclone of } \\
\text { pREP1 }\end{array}$ & This work \\
\hline pREP27 & $\begin{array}{l}\text { pBluescript harbouring the E. carotovora subsp. } \\
\text { atroseptica SCRI } 27 k d g R\end{array}$ & This work \\
\hline pREP14 & $\begin{array}{l}\text { pBluescript harbouring the } E \text {. carotovora subsp. } \\
\text { carotovora F14 kdgR }\end{array}$ & This work \\
\hline pREP148 & $\begin{array}{l}\text { pBluescript harbouring the E. carotovora subsp. } \\
\text { carotovora F148 } k d g R\end{array}$ & This work \\
\hline
\end{tabular}

*Genotype symbols are according to Bachmann (Basham \& Bateman, 1975). $l m r T$ e indicates that the transport system encoded by $l m r T$, which mediates entry of lactose, melibiose and raffinose into the cells, is constitutively expressed. lac $Z^{\prime}$ indicates that 3 ' end of this gene is truncated.

in T-TBS containing $1 \%$ gelatin as previously described (Praillet et al., 1996). Membranes were developed using the ECL kit (Amersham), according to the manufacturer's instructions.

\section{RESULTS}

\section{Sequence analysis}

During analysis of the E. carotovora subsp. carotovora strain ATTn10 genes responsible for production of the $\beta$-lactam antibiotic carbapenem, a partial ORF was identified downstream from these car genes and transcribed on the opposite strand (McGowan et al., 1996). This ORF potentially encoded the C-terminus of a protein with homology to the Kdul protein of $E$. chrysanthemi. It was decided to extend the sequence in the region, in order to identify the $5^{\prime}$ end of this gene, on the cosmid cWU142.

Following restriction mapping of cWU142, to identify EcoRI fragments contiguous with the $3^{\prime}$ end of the carbapenem biosynthetic cluster, two fragments were cloned in pUC19 (Yanisch-Perron et al., 1985). These fragments were either cloned directly in M13mp18 or were sonicated and the resulting fragments ligated into M13mp19. Analysis of the resulting subclones by the dideoxynucleotide chain-termination method (Sanger $e t$ al., 1977) generated $3080 \mathrm{bp}$ of DNA sequence. Part of this sequence has already been reported (McGowan $e t$ al., 1996) and therefore the novel sequence reported here will be lodged with GenBank under the already existing accession number, U17224.

Upon translation of the DNA sequence generated, several ORFs were identified. The previously recognized partial ORF was completed. It was predicted to encode a protein of 276 amino acids, with a molecular mass of $31071 \mathrm{Da}$, which presents high homology with the 5keto-4-deoxyuronate isomerase (KduI) of E. chrysanthemi $(65 \%$ aa identity) and with two proteins of Escherichia coli and Bacillus subtilis $(66 \%$ and $47 \%$ aa identity, respectively). Accordingly we have designated this gene $k d u I$. Two other ORFs were identified. Based on homologies with previously described genes, one of these ORFs was designated $k d g T . k d g T$ is predicted to encode a protein of 318 amino acids with a molecular mass of $32581 \mathrm{Da}$ which shares $54 \%$ and $74 \%$ aa identity with the 2-keto-3-deoxygluconate transporter of B. subtilis and Escherichia coli, respectively. The predicted E. carotovora subsp. carotovora KdgT protein also displayed high homology with 318 out of 398 residues of the E. chrysanthemi KdgT protein. The Nterminus of the E. chrysanthemi $\mathrm{KdgT}$ protein is significantly longer than all those of the known KdgT homologues (data not shown). In the absence of experimental data therefore, it is possible that the previously assigned translational start site of the $E$. chrysanthemi $k d g T$ ORF is incorrect and that its true start site lies at a position analogous to that in the other previously reported $k d g T$ homologues.

The third ORF whose predicted product has homology with the KdgR protein of E. chrysanthemi was originally referred to as unpublished data in a previous paper (Salmond et al., 1994). However, on completion of the sequence and the analysis of an allelic exchange mutant defective in this ORF it was renamed rexZ (regulator of exoenzymes) due to its unexpected phenotype (see following section).

The rex $Z$ gene is predicted to encode a protein of 262 amino acids with a molecular mass of $29516 \mathrm{Da}$. Using oligonucleotide primers (Eck1 and Eck2) complementary to the terminal $5^{\prime}$ and $3^{\prime}$ sequences, respectively, of the E. carotovora subsp. carotovora strain ATTn10 rexZ gene, we also amplified the $\operatorname{rex} Z$ gene from the $\mathrm{Car}^{-}$E. carotovora subsp. carotovora strain SCRI193 for comparison. The E. carotovora subsp. carotovora SCRI193 rexZ was almost identical to that of strain ATTn10 (Fig. 1). Database searches revealed that the $E$. carotovora RexZ protein presents some homology with proteins from E. chrysanthemi, B. subtilis and Es- 
$\operatorname{RexZ} 10$

$\operatorname{Rexz} 193$

KdgR F14

KdgR 193

KdgR F14

KdgR 27

KdgR ECH

KdgR ECO

ICIR ECO

ICIR STY

GYIR SCO

YYIR SGR

Pir ECH

Pir ECH

YiaJ HIN

YbbU ECO

YfaX ECO

YjhI ECO

YCSO BAS

MhPR ECO

$\operatorname{Rexz} 10$

Rexz 193

KdgR F14

KdgR 193

KdgR F148

KdgR 27

KdgR ECH

KdgR ECO

ICIR ECO

ICIR STY

GylR SCO

GYIR SGR

YiaJ ECO

Pir ECH

YiaJ HIN

YagI ECO

YfaX ECO

YjhI ECO

YCSO BAS
MhpR ECO

Rexz 10

Rexz 193

KdgR F14

KdgR 193

KdgR F148

$\begin{array}{ll}\text { KdgR } & F 148 \\ \text { KdgR } 27\end{array}$

KagR 27

KdgR ECH

KdgR ECO

ICIR ECO

ICIR STY

$\begin{array}{ll}\text { GylR } & \text { SCO } \\ \text { GylR SGR }\end{array}$

YiaJ ECO

Pir ECH

YiaJ HIN

YagI ECO

YbbU ECO

Y faX ECO

YjhI ECO

YCSO BAS

MhpR ECO
20 * 40

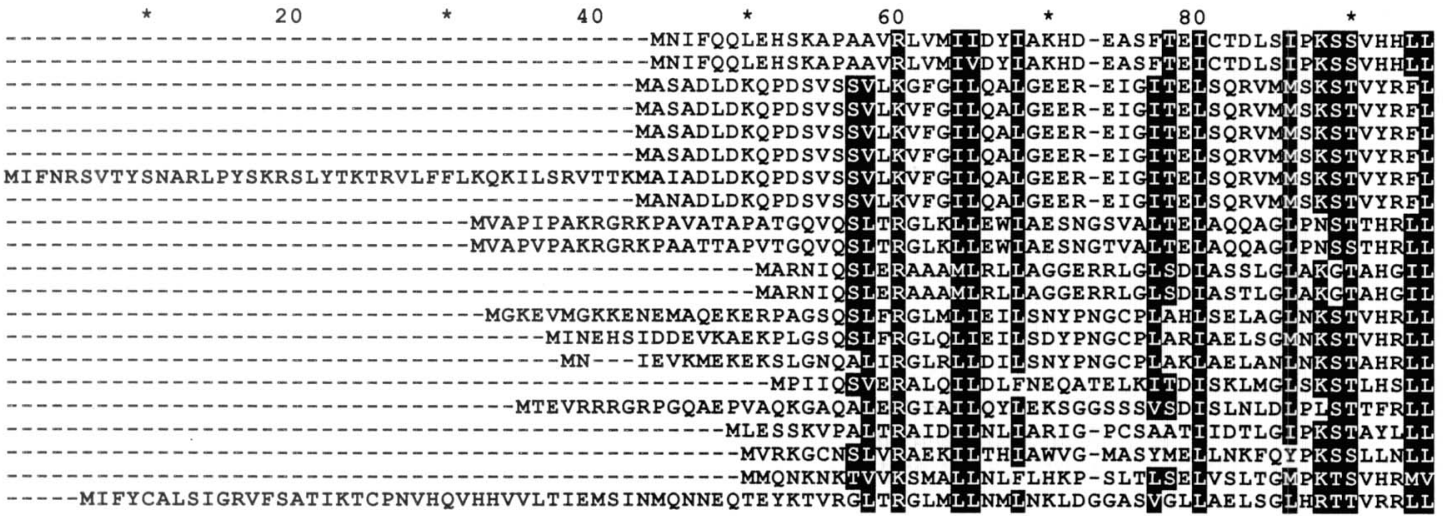

51
51
52
52
52
52
94
52
64
64
45
45
63
59
55
44
61
46
45
45
90

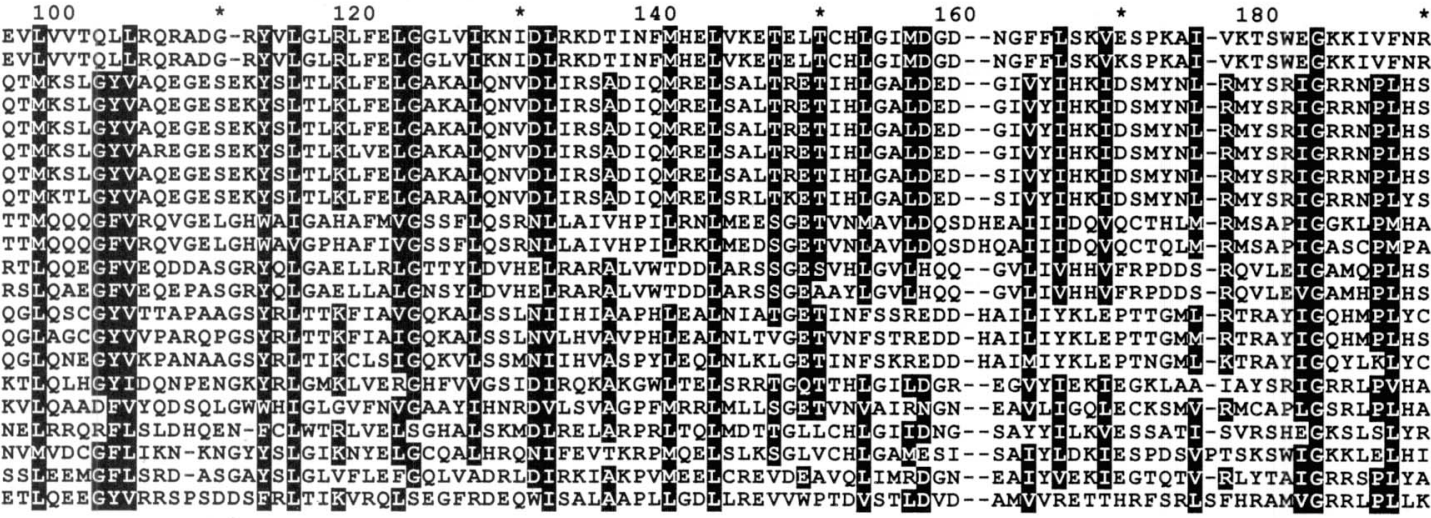

142

142

144

144

144

186

144

158

158
137

137

156

152

152

148

136

153

137

137

136
183

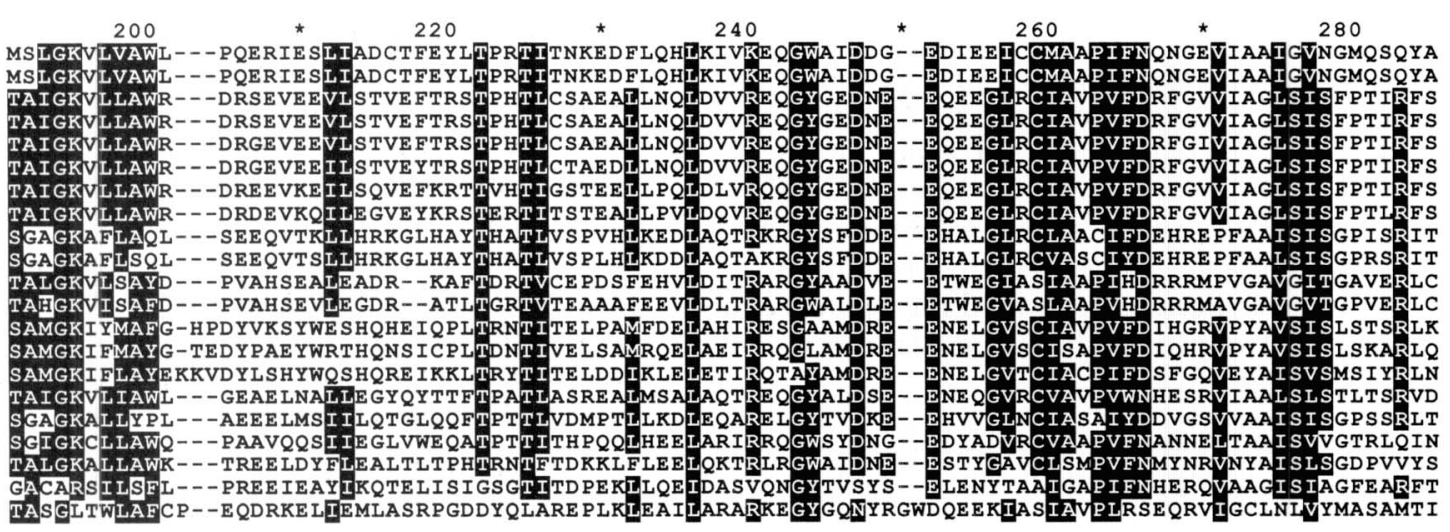

232

232
234

234

234
234

234
276

276

234

248

248
225

225

248

244

241

226

27

227

226

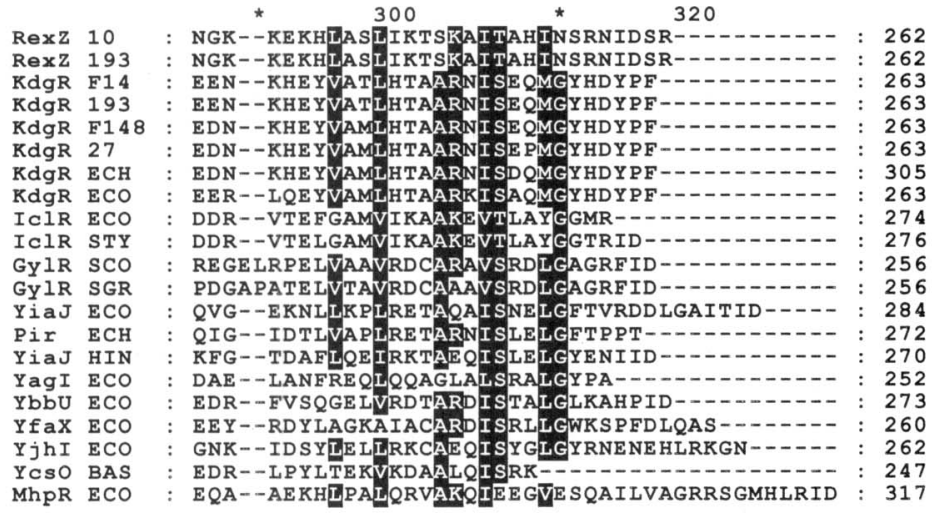

Fig. 1. Alignment of the predicted amino acid sequences of the RexZ and KdgR homologues characterized in this study from the following strains: $E$. carotovora subsp. carotovora strains ATTn 10 (10; accession number U17224), SCRI193 (193; accession numbers AF135394 and AF135787), F14 (F14; accession number AF135395) and F148 (F148; accession number AF135396); E. carotovora subsp. atroseptica strain SCRI27 (27; accession number AF135397). The above sequences are 

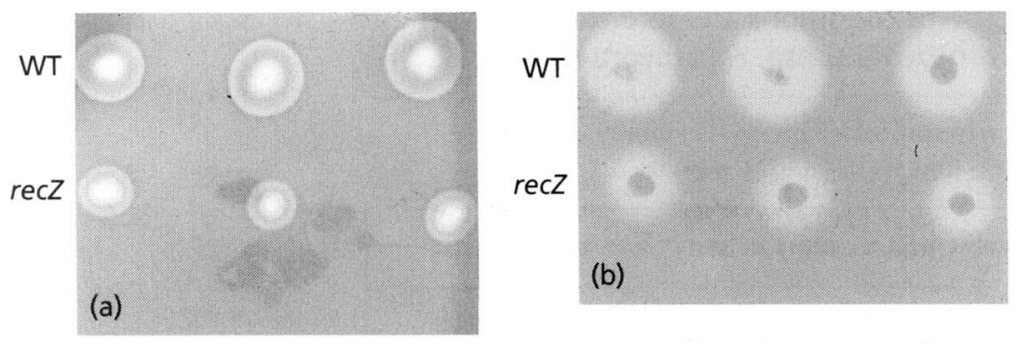

WT

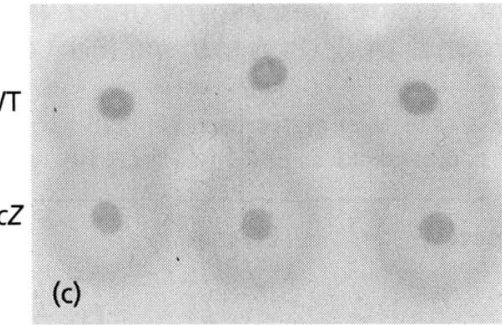

Fig. 2. Phenotypic analysis of the Erwinia carotovora Rexz ${ }^{-}$marker-exchange mutant. Cultures of the wild-type Erwinia carotovora strain ATTn 10 (WT) and Erwinia carotovora rexZ::kan strain SM2 (rexZ) were spotted onto assay plates for the production of cellulase (a), protease (b) and pectate lyase (c). The production of exoenzymes on these assay plates is indicated by the presence of a halo.

cherichia coli, all of which are members of the IclR family of DNA-binding proteins (Fig. 1; Sunnarborg et al., 1990). The homologous E. chrysanthemi protein is the major repressor of genes involved in pectinolysis, KdgR. As previously reported for E. chrysanthemi $\mathrm{KdgR}$, the E. carotovora RexZ possesses a possible helix-turn-helix, DNA-binding motif in the N-terminus and a conserved region in the C-terminus that corresponds to the signature pattern for the IclR family of proteins: [GA]-X $\mathrm{X}_{3}$-[DS]- $\mathrm{X}_{2}-\mathrm{E}-\mathrm{X}_{6}$-[CSA]-[LIVM][GSA]-X ${ }_{2}$-[LIVM]-[FYH]-[DN] (Reverchon et al., 1991; Sofia et al., 1994). The putative helix-turn-helix and IcIR family signature motifs are located in RexZ between residues 33-52 (FTEICTDLSIPKSSVHHLLE) and 192-213 (GWAIDDGEDIEEICCMAAPIFN), respectively. Since the helix-turn-helix motifs are known to be involved in protein-DNA interactions (Harrison \& Aggarwal, 1990), it was reasonable to assume that RexZ is a DNA-binding protein.

\section{Construction and characterization of an $E$. carotovora rexZ null mutant strain}

In contrast with the homologies between the KduI and KdgT proteins from E. chrysanthemi and E. carotovora, which are high, the homology between the E. carotovora RexZ protein and the $E$. chrysanthemi $\mathrm{KdgR}$ repressor is low (26\% identity; Fig. 1). Given this low homology, and the wide spectrum of physiological roles that other members of the IcIR protein family perform (Reverchon et al., 1991; Smith \& Chater, 1988; Sunnarborg et al., 1990), we considered it imperative to determine the phenotype of a rex $Z$ null mutant. Southern blot analysis of subclones of the carbapenem biosynthetic cosmid cWU142 (McGowan et al., 1995) indicated that plasmid pMO11 (McGowan et al., 1997) carried rexZ (data not shown). The $2.8 \mathrm{~kb}$ of chromosomal DNA insert carried by pMO11 was cloned in pKNG101 and used to mutate the chromosomal rex $\mathrm{Z}$ gene by marker exchange (see Methods). Southern blot analysis of the chromosomal DNA of several of the resulting exconjugants was carried out to confirm that marker exchange of the wild-type gene had taken place with fidelity (data not shown). The rexZ::kan marker-exchange mutant strain SM2 was used for all further analysis.

Comparison of the production of virulence-associated factors in the E. carotovora rex Z mutant strain SM2 and in the wild-type strain allowed us to assess the function of rexZ. Plate assays revealed that pectate lyase, cellulase and protease activity was reduced in the mutant compared to the parental strain (Fig. 2). These results suggest that the E. carotovora RexZ protein acts as an activator of exoenzyme synthesis. The more sensitive liquid enzyme assays revealed that the production of cellulase and protease was reduced by $86 \%$ and $63 \%$, respectively, in a RexZ $Z^{-}$mutant when compared to the wild-type E. carotovora strain ATTn10 (data not shown). Liquid enzyme assays also showed that the pectate lyase activity was reduced fourfold in the mutant either in the absence or in the presence of PGA (Table 2) when compared to the wild-type strain ATTn10. This unexpected result demonstrated that, although $\operatorname{RexZ}$ and the $\mathrm{KdgR}$ proteins share sequence

aligned with the other members of the ICIR family of regulatory proteins from the following species: Escherichia coli (ECO) - KdgR (transcriptional regulator of $k d g K$ and $k d g T$; accession number P76268), Yjhl (hypothetical protein; accession number P39360), Yagl (hypothetical protein; accession number P77300), YfaX (hypothetical protein; accession number P77732), ICIR (repressor of the acetate operon; accession number P16528), YiaJ (hypothetical protein; accession number P37671), YbbU (hypothetical protein; accession number P77734), MhpR (activator of the 3hydroxyphenylpropionate degradation pathway; accession number P77569); Erwinia chrysanthemi (ECH)-KdgR (regulator of pectinolysis; accession number X62072), Pir (regulator of virulence; accession number AB017637); Bacillus subtilis (BAS) - YcSO (hypothetical protein; accession number P42968); Salmonella typhimurium (STY) - IcIR (repressor of the acetate operon; accession number P17430); Haemophilus influenzae (HIN) - YiaJ (hypothetical protein; accession number P44996); Streptomyces griseus (SGR) - GylR (regulator of the glycerol operon; accession number P22866); and Streptomyces coelicolor (SCO) - GylR (regulator of the glycerol operon; accession number P15360). Black shading has been used to indicate positions at which at least 15 out of the 21 residues are either identical or similar, as assigned by GeneDoc (version 2.2). 
Table 2. Pectate lyase activity under various growth conditions and in different genetic backgrounds of $E$. chrysanthemi (Ech) and $E$. carotovora subsp. carotovora (Ecc)

Enzyme assays were performed on cells grown to early stationary phase. Pectate lyase specific activity is expressed as $\mu \mathrm{mol}$ products liberated $\min ^{-1}$ ( $\mathrm{mg}$ bacterial dry weight $)^{-1}$.

\begin{tabular}{|c|c|c|c|c|c|}
\hline \multirow[t]{2}{*}{ Inducer } & \multirow[t]{2}{*}{ Plasmid } & \multicolumn{4}{|c|}{ Specific pectate lyase activity in strain: } \\
\hline & & $\begin{array}{c}\text { Ecc ATTn } 10 \\
\text { (wild-type) }\end{array}$ & $\begin{array}{r}\text { Ecc SM2 } \\
\left(\operatorname{Rex} Z^{-}\right)\end{array}$ & $\begin{array}{c}\text { Ech } 3937 \\
\text { (wild-type) }\end{array}$ & $\begin{array}{c}\text { Ech A903 } \\
\left(\mathrm{KdgR}^{-}\right)\end{array}$ \\
\hline- & - & $0 \cdot 15$ & 0.04 & $0 \cdot 11$ & $1 \cdot 80$ \\
\hline- & pROU2* & 0.04 & 0.01 & $0 \cdot 05$ & $0 \cdot 30$ \\
\hline PGA & - & 1.90 & $0 \cdot 34$ & $1 \cdot 60$ & $2 \cdot 50$ \\
\hline PGA & pROU2* & 0.76 & $0 \cdot 18$ & $0 \cdot 70$ & $0 \cdot 85$ \\
\hline
\end{tabular}

"pROU2 is a pULB113 derivative harbouring $k d g R$ of E. chrysanthemi.

identity, they are not functional homologues and that, unlike the E. chrysanthem $i \mathrm{KdgR}$, the activity of RexZ is not modulated by pectinolytic intermediates (Table 2; Reverchon et al., 1989; Nasser et al., 1991). Further investigations of the action of RexZ on exoenzyme gene expression were therefore warranted.

\section{Overproduction and purification of RexZ}

To investigate whether RexZ indeed interacts with the regulatory regions of the exoenzyme genes, as suggested by the presence of a helix-turn-helix motif in its sequence, we overproduced RexZ using the T7 RNA polymerase system (Tabor \& Richardson, 1985). Under the standard conditions, the overproduced RexZ protein precipitated and formed inclusion bodies. Various approaches (chemical treatment, changes in the conditions of growth or induction) used to try to resolubilize the overproduced RexZ protein were unsuccessful. However, the unusual solubility properties of RexZ were exploited to purify the protein on a preparative SDS-PAGE gel. Purified protein was used for the generation of specific anti-RexZ antibodies.

\section{The regulation of expression of rex $Z$ by $\mathrm{KdgR}$ and CRP}

Previous studies have shown that the major regulators of genes involved in pectinolysis in E. chrysanthemi are CRP and KdgR (Reverchon et al., 1997; Nasser et al., 1997). Interestingly, computer searches looking for consensus sequences recognized by regulatory proteins characterized in E. carotovora or E. chrysanthemi revealed the presence of potential binding sites for CRP and $\mathrm{KdgR}$ in the promoter region of the rexZ gene (Fig. $3 a)$. To establish the precise location of any potential cAMP-CRP and KdgR binding sites in the regulatory region of the rex $Z$ gene, $\mathrm{DN}$ ase I protection experiments were conducted. A single protected region with an average length of approximately 36 and $47 \mathrm{bp}$ was obtained in the presence of cAMP-CRP and KdgR at either subsaturating or saturating concentrations, re- spectively. These protected regions encompass the predicted CRP-binding site and the KdgR box (Fig. 3a, b). The cAMP-CRP-binding site is centred at position -41.5 with respect to the putative transcription start site of rexZ, which is typical for class II CRP-dependent promoters (Fig. 3a). This result suggests that the cAMP-CRP complex could act directly as an activator of the rexZ promoter. However, the KdgR-protected region covers the nucleotides between -67 and -110 ; this makes it unlikely that the binding of $K \mathrm{dgR}$ would interfere with the expression of the rex $Z$ promoter, and therefore suggests that the rex $Z$ promoter is independent of KdgR repressor control. In the absence of a direct effect on rexZ expression it was formally possible that, because the binding sites of $K d g R$ and CRP are close together (Fig. 3a), KdgR may affect rexZ expression by interfering with the ability of cAMP-CRP to bind DNA and therefore activate gene expression.

To determine whether CRP and KdgR could indeed interact with the regulatory region of rexZ in a cooperative, independent or antagonistic way, we performed gel retardation assays using the E. chrysanthemi purified CRP and KdgR proteins. Typical results of band shifts obtained in the presence of the KdgR or CRP protein and the rex $Z$ regulatory region are shown in Fig. 4(a). Two clearly separate bands, corresponding to free DNA and a DNA-protein complex, were observed when the rex $Z$ operator was incubated with either CRP or KdgR, suggesting the existence of a unique CRPbinding site and a unique $\mathrm{KdgR}$ box in the rexZ regulatory region. The mutual influence of CRP and $\mathrm{KdgR}$ on the ability to bind the rexZ regulatory region was estimated by using control reactions containing only one of these two proteins. The addition of a subsaturating quantity of $\mathrm{KdgR}$ and CRP to a solution containing the rex $Z$ promoter fragment resulted in three protein-DNA complexes: two corresponding to the KdgR-DNA and cAMP-CRP-DNA individual complexes and one corresponding to cAMP-CRPKdgR-DNA complex. At a saturating concentration of 
(a)

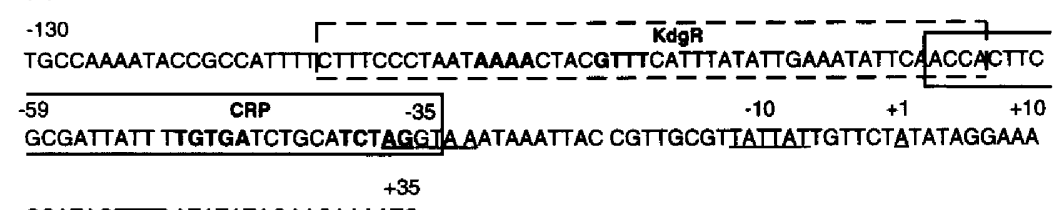

CCATAGTIT ATATATAGAACAAAATG

(b)

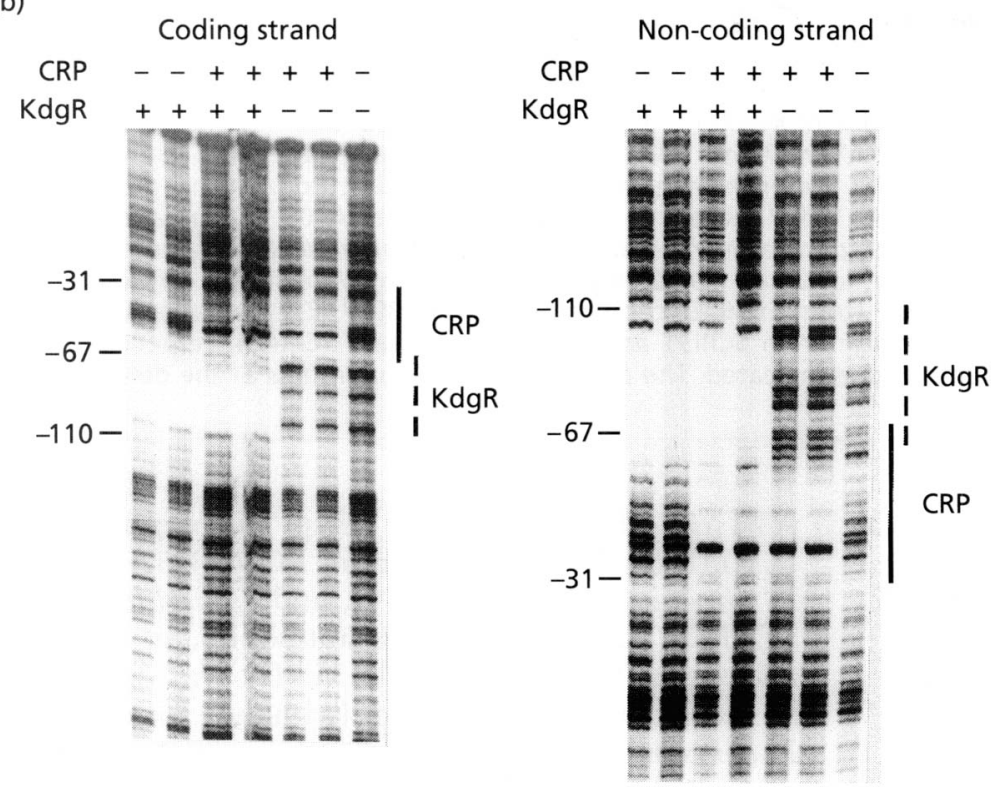

\begin{abstract}
Fig. 3. (a) Organization of the promoter-operator region of rexz. The sequence is numbered from the putative transcription start site, base ' $A$ ', shown underlined at position +1 . Regions corresponding to the putative -10 and -35 promoter sites are labelled and underlined. The sequences contained within the brokenand solid-lined boxes represent the binding sites for KdgR and CAMP-CRP, respectively, as defined by DNase I footprinting experiments. The emboldened nucleotides contained within the broken- or solid-lined boxed regions correspond to the sequences that share homology with the consensus binding site for KdgR and CAMP-CRP, which are (AAT[G/A]AAA[C/T])N(N[T/G][G/A]TTT[C/T]A) (Nasser et al., 1994) and AATGTGAN 6 TCACATT (Kolb et al., 1993), respectively. The putative ATG translation initiation codon has been underlined at position +35 . (b) DNase I footprinting of the CAMP-CRP and KdgR binding sites within the promoter-operator region. Purified proteins were used for DNase I footprinting at a final concentration of 100 or $200 \mathrm{nM}$ for $\mathrm{KdgR}$ and 50 or $100 \mathrm{mM}$ for CRP.
\end{abstract}

(a)

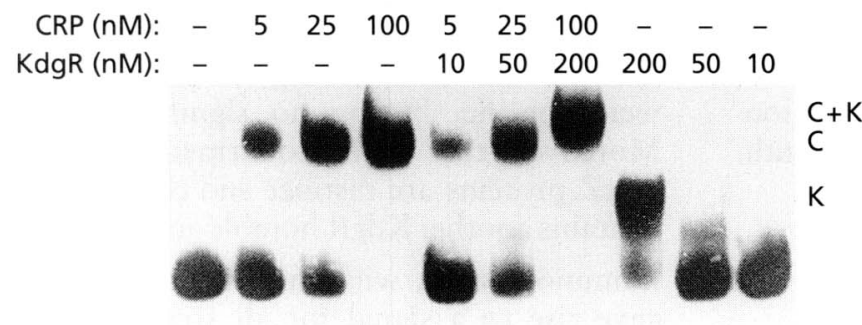

(b)

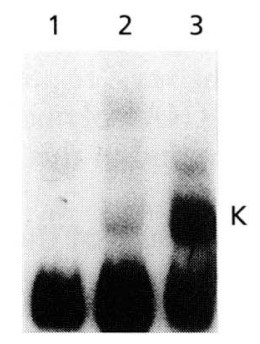

Ecc rexz

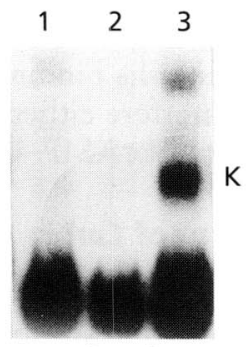

Ech pelE

Fig. 4. (a) Analysis of the CAMP-CRP-KdgR (Ech) ternary complex formation with the rexZ regulatory region from Ecc. $C_{r}$ $K$, and $C+K$ correspond to the DNA-protein complexes involving CAMP-CRP, KdgR, and both CAMP-CRP and KdgR, respectively. The concentration of each protein added to the reaction mix is indicated above. (b) Interactions between the Ecc rexZ and Ech pelE operator-regulatory regions with the partially purified KdgR protein from Ecc strain SCRI193. Twenty micrograms of the ECc SCRI193 partially purified KdgR protein (contained in the $20-40 \%$ ammonium sulphate saturated fraction) was incubated with the respective operator DNA fragment (lane 3 ). K corresponds to the DNA-protein complexes involving KdgR. In lanes 1 and 2 the partially purified KdgR protein was first incubated with 4 mM KDG or $1 \mu \mathrm{l}$ of the anti-KdgR antibodies, respectively, prior to the addition of the operator DNA fragments. Ecc and Ech denote $E$. carotovora subsp. carotovora and $E$. chrysanthemi, respectively.

$\mathrm{CRP}$ and $\mathrm{KdgR}$ proteins, only a ternary complex was observed (Fig. 4a). Simultaneous binding of both regulators did not modify their respective affinity for the rexZ operator (data not shown). DNase I footprinting experiments revealed that the KdgR and cAMP-CRP binding sites partially overlap on the rex $Z$ promoter-operator region (Fig. 3a, b). This finding suggests that CRP and KdgR are likely to bind to different sides of the DNA helix so that it is possible for them to bind simultaneously on the same stretch of DNA. A similar situation was previously reported for the E. chrysanthemi pelC gene (Nasser et al., 1997).

To obtain additional evidence for the possible role of cAMP-CRP as a regulator of rexZ expression in vivo, quantitative analysis of the RexZ protein was performed 
(a)

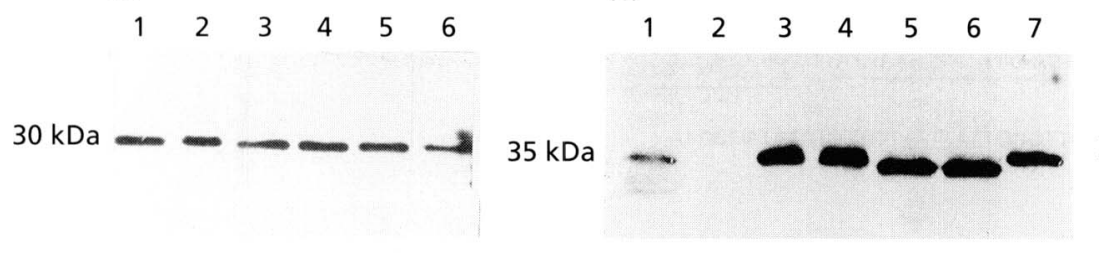

(b)

(c)

$30 \mathrm{kDa}$

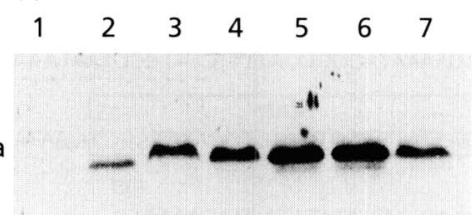

Fig. 5. (a) Quantification of RexZ produced in different genetic backgrounds or from bacteria grown under differing conditions; (b, c) occurrence of KdgR (b) and RexZ (c) homologues in different strains of Erwinia spp. Cultures were grown to a cell density of $4 \times 10^{8}(\mathrm{a}, \mathrm{c})$ or $1 \times 10^{8}(\mathrm{~b})$ cells $\mathrm{ml}^{-1}$. Crude protein extracts, made from these cultures, were immunoblotted, after SDS-PAGE separation, and incubated with KdgR- (b) or RexZ- (a, c) specific antibodies. (a) Lanes 1, 2 and 3, E. carotovora subsp. carotovora strains SCRI193, ATTn 10 and PNP22 (carl'), respectively; lanes 4, 5 and 6, E. carotovora subsp. carotovora strain ATTn 10 grown in the presence of galacturonate, polygalacturonate and glucose, respectively. (b) Lanes 1 to $7, E$. amylovora strain SCRI449, kdgR mutant $E$. chrysanthemi strain A903, E. chrysanthemi strain EC16, E. chrysanthemi strain 3937, E. carotovora subsp. carotovora strain ATTn 10, E. carotovora subsp. atroseptica strain SCRI31 and E. herbicola strain SCRI424, respectively. (c) Lanes 1 to 7, rexZ mutant $E$. carotovora subsp. carotovora strain SM2, E. amylovora strain SCRI449, E. chrysanthemi strain EC16, E. chrysanthemi strain 3937, E. carotovora subsp. carotovora strain ATTn 10, E. carotovora subsp. atroseptica strain SCRI31 and E. herbicola strain SCRI424, respectively. Cultures were grown at $30^{\circ} \mathrm{C}$ in LB medium supplemented as indicated. The approximate molecular mass of the detected proteins is indicated on the left.

in E. carotovora cells grown in the presence or absence of glucose, using anti-RexZ antibodies. This experiment revealed a significant reduction in the amount of RexZ in cells grown in the presence of glucose (Fig. 5a). However, immunoblotting experiments performed using cell extracts from cultures grown in the presence or absence of PGA or galacturonate did not show any significant variation in the quantity of the Rex $Z$ protein (Fig. 5a). These data, combined with the in vitro binding of cAMP-CRP to the rex $Z$ promoter region, suggest that, although cAMP-CRP acts directly to control rexZ expression, $K d g R$ is not a repressor of the expression of this gene since its binding on the rex $\mathrm{Z}$ regulatory region does not interfere either with RNA polymerase or with the capacity of cAMP-CRP to bind in this region.

\section{Involvement of Carl in the synthesis of the Rexz protein}

In E. carotovora subsp. carotovora, degradative exoenzyme synthesis is regulated by quorum sensing, via the production of OHHL, which is directed by CarI/ ExpI/HsII (Jones et al., 1993; Pirhonen et al., 1993; Chatterjee et al., 1995). In an attempt to determine whether RexZ production is controlled by OHHL, we performed Western blot experiments with protein extracts from E. carotovora PNP22 $\left(\mathrm{Carl}^{-}\right)$. No differences were noted in the quantity of RexZ in the parental strain and the carI mutant (Fig. 5a). Thus, it is unlikely that RexZ synthesis is regulated by OHHL. These data may also suggest that RexZ and CarI are involved in two distinct activation mechanisms of exoenzyme synthesis.

\section{Occurrence of RexZ and KdgR in Erwinia spp.}

Immunoblotting experiments conducted with antibodies raised against the E. chrysanthemi $\mathrm{KdgR}$ or E. carotovora subsp. carotovora RexZ proteins were used to detect these proteins in cell extracts of different strains: E. carotovora subsp. carotovora strains SCRI193 and
ATTn10, E. carotovora subsp, atroseptica strain SCRI31, E. chrysanthemi strains EC16, 3937 and A903, E. amylovora strain SCRI449, and E. herbicola strain SCRI429. Using anti-KdgR antibodies, a band corresponding to approximately $35 \mathrm{kDa}$ was detected for all the E. chrysanthemi strains (with the exception of the E. chrysanthemi kdgR mutant strain A903), in addition to E. herbicola and E. amylovora (Fig. 5b). A smaller band was observed for E. carotovora subsp. carotovora strain ATTn10 and strain SM2 (rexZ; data not shown) as well as E. carotovora subsp. atroseptica. These data showed that the anti-KdgR and anti-RexZ antibodies were specific, having no significant cross-reactivity. Moreover, this result confirmed that the $\mathrm{KdgR}$ and RexZ proteins are distinct and that E. carotovora also contains another KdgR homologue, in addition to RexZ.

Immunoblotting with anti-RexZ antibodies (Fig. 5c) gave rise to a signal for all strains except for the $E$. carotovora rex $\mathrm{Z}$ mutant strain SM2. The detected proteins all have a molecular mass of approximately $30 \mathrm{kDa}$ (Fig. 5c). These data showed that the RexZ protein is well conserved in pectinolytic Erwinia species. The presence of a possible homologue of RexZ in $E$. chrysanthemi is especially interesting because the majority of the proteins that are known to control exoenzyme production in this genetic background are negative regulators.

The bands corresponding to the RexZ proteins of the non-pectinolytic Erwinia strains (E. amylovora and $E$. herbicola) were of lower intensity. This may indicate that RexZ is less abundant in non-pectinolytic species, or perhaps these species contain a more distantly related protein.

\section{Isolation and analysis of the $E$. carotovora subsp. carotovora $k d g R$ homologue}

Immunoblotting with anti-KdgR (E. chrysanthemi) and anti-RexZ antibodies revealed that, in addition to RexZ, 
E. carotovora possessed another $\mathrm{KdgR}$ homologue. To isolate the corresponding $k d g R$ gene we first used PCR to amplify a $915 \mathrm{bp} k d g R$-specific gene probe from chromosomal DNA of E. chrysanthemi 3937. This 'DIG-11-dUTP'-labelled gene probe was used in a Southern blot to probe the chromosomal DNA of $E$. carotovora subsp. carotovora, which had been digested with various restriction enzymes. The results indicated that the E. carotovora subsp. carotovora $k d g R$ homologue was located on a $6 \mathrm{~kb} E c o$ RV DNA fragment (data not shown). Based on this result, an E. carotovora subsp. carotovora chromosomal DNA mini-library was constructed in pACYC184 (Chang \& Cohen, 1978) and probed with the $k d g R$-specific gene probe. Of the 300 library clones screened one, pREP1, was identified by Southern blotting to carry the putative $k d g R$ gene. Restriction analysis of pREP1 revealed that it carried two simultaneously cloned $6 \mathrm{~kb}$ chromosomally derived DNA inserts. Subclones of pREP1 were made in pUC19 and probed with the $k d g R$ gene probe in a Southern blot. The putative E. carotovora subsp. carotovora $k d g R$ gene was mapped to a $2 \cdot 1 \mathrm{~kb} E c o \mathrm{RV}-S p h \mathrm{I}$ fragment carried on a subclone denoted pREP4. The insert of pREP4 was sequenced and a total of $2173 \mathrm{bp}$ of nucleotide sequence was generated (accession number AF135787).

The predicted translation of this sequence revealed one complete and one partial ORF. The first partial ORF, denoted ' $o g l$, was predicted to encode the C-terminal 153 amino acids of a protein which shared a high level of homology with Ogl from E. chrysanthemi and $E$. carotovora subsp. atroseptica. Following restriction mapping of pREP4, the contiguous $S p h \mathrm{I}-E c o \mathrm{RV}$ fragment was identified and sequenced, completing the sequence of the E. carotovora subsp. carotovora ogl ORF (accession number AF135787). The ogl ORF was predicted to encode a $44426 \mathrm{Da}$ protein of 388 amino acids. Database searches showed that the predicted product of this gene shared $99 \%$ and $87 \%$ sequence identity with the E. carotovora subsp. atroseptica and $E$. chrysanthemi $\mathrm{Ogl}$ proteins, respectively.

The second ORF on pREP4, denoted $k d g R$ (based on sequence homology), was predicted to encode a $29700 \mathrm{Da}$ protein of 263 amino acids. Homology searches showed that the predicted product of this ORF shared a high level of homology with Escherichia coli $\mathrm{KdgR}$ ( $88 \%$ identity) and also with 263 amino acids out of the 305 amino acids that constitute the E. chrysanthemi KdgR protein (95\% identity; Fig. 1). The predicted E. carotovora subsp. carotovora KdgR lacked the N-terminal 42 amino acids present in the $\mathrm{KdgR}$ protein from the related species, E. chrysanthemi.

To further characterize KdgR homologues from subspecies of $E$. carotovora, additional $k d g R$ genes were isolated by PCR amplification, using primers KD1, KD3 and KD5. The purified PCR-amplified products from $E$. carotovora subsp. atroseptica strain SCRI27, and from E. carotovora subsp. carotovora strains F14 and F148, were cloned into pBluescript (Stratagene) cut with SmaI, generating pREP27, pREP14 and pREP148, respectively. Sequence analysis of these putative $k d g R$ clones revealed that they each carried a single ORF, the predicted products of which shared high homology with the previously described $\mathrm{KdgR}$ proteins (Fig. 1). The predicted KdgR proteins of these strains of Erwinia spp. also lack the $\mathrm{N}$-terminal 42 amino acids displayed by the homologous E. chrysanthemi protein.

\section{$\mathrm{N}$-terminal sequence analysis of the $E$. carotovora subsp. carotovora SCRI193 KdgR protein}

To definitively identify the translational start site of the E. carotovora subsp. carotovora SCRI193 KdgR protein, a recombinant protein was purified by virtue of six histidine residues (6-His tag) which had been added on to the C-terminus of the protein (see Methods). The construct carried a total of 1557 bp of PCR-amplified $E$. carotovora subsp. carotovora insert DNA, including 677 bp of DNA upstream of the putative E. carotovora $k d g R$ ORF, assumed to include the $k d g R$ promoter region. A protein of approximately $30 \mathrm{kDa}$ was observed, which was consistent with the predicted size of the E. carotovora $\mathrm{KdgR}$. The resultant N-terminal amino acid sequence generated from this clone agreed with that previously predicted from the nucleotide sequence of $k d g R$ (Fig. 1). The E. carotovora KdgR protein is therefore analogous to the $\mathrm{KdgR}$ protein predicted for Escherichia coli and all the other $\mathrm{KdgR}$ homologues identified in this study. It is obvious from these data that although the gene order of $o g l$ and $k d g R$ is retained and the $o g l$ genes themselves are highly conserved between the Erwinia spp., there are significant differences between the $\mathrm{N}$-terminal regions of the predicted KdgR proteins of the two E. carotovora subspecies compared to that previously reported for $E$. chrysanthemi.

\section{Functional interchangeability of the $E$. chrysanthemi and $E$. carotovora subsp. carotovora KdgR proteins}

Functional interchangeability has been demonstrated for the Escherichia coli and E. chrysanthemi $\mathrm{KdgR}$ proteins, where the $E$. coli homologue was shown to be able to repress pelD transcription (James \& HugovieuxCotte-Pattat, 1996). To test whether the KdgR proteins of E. carotovora and E. chrysanthemi were interchangeable, we performed band-shift experiments by using protein extracts from E. carotovora subsp. carotovora and the regulatory regions of both the E. carotovora rex $Z$ gene and the E. chrysanthemi pelE gene, encoding a major pectate lyase. Partially purified KdgR protein from E. carotovora subsp. carotovora SCRI193, obtained after fractionated precipitation with ammonium sulphate, was used in gel retardation assays. One major DNA-protein complex was observed when $K d g R$ was incubated with either the pelE or rexZ operator regions (Fig. 4b). The addition of KdgR-specific antibodies or KDG (the actual inducer of the pectinolysis genes) to the reaction mix, prior to the incubation of 
KdgR with the DNA operator regions, inhibited the formation of both complexes (Fig. 4b). Thus the $E$. carotovora KdgR protein appears to be able to bind to a DNA fragment containing a KdgR-box. Consequently, it is reasonable to assume that the E. chrysanthemi and E. carotovora $\mathrm{KdgR}$ proteins are interchangeable. This was confirmed by the fact that the introduction of an Rprime plasmid (pROU2) containing the E. chrysanthemi wild-type $k d g R$ gene (Reverchon et al., 1991) in $E$. carotovora decreased the pectate lyase activity by twoto fivefold in both ATTn10 and SM2 strains (Table 2).

\section{DISCUSSION}

This study was initiated by the fortuitous discovery that E. carotovora possessed a gene, rexZ, encoding a homologue of the major repressor of pectinolysis (KdgR) in E. chrysanthemi. Because sequence identity between the two proteins was limited, we thought it prudent to further investigate the relationship between the $E$. chrysanthemi $k d g R$ and $E$. carotovora rex $Z$ gene products. In order to determine whether $\operatorname{Rex} Z$ was a functional homologue of $K d g R$, we constructed a rex $Z$ null mutant. The E. carotovora RexZ $\mathrm{Z}^{-}$mutant exhibited a reduced level of pectate lyase, cellulase and protease production and therefore RexZ, in contrast to KdgR, was likely to be an activator rather than a repressor of exoenzyme production. In addition, functional studies revealed that, unlike in the E. chrysanthemi $k d g R$ mutant (where the $\mathrm{KdgR}^{-}$phenotype can be phenotypically suppressed by the presence of PGA), the activity of RexZ protein is not modulated by pectic compounds (Table 2). This was unexpected, and confirmed that the E. carotovora $\mathrm{RexZ}$ regulatory protein is not a functional homologue of the E. chrysanthemi KdgR repressor, but acts in an antagonistic fashion as a novel activator of virulence in $E$. carotovora.

Sequence analysis of the rex $Z$ promoter region revealed the presence of consensus binding sites for KdgR and CRP. In an attempt to determine the relative position that RexZ occupies in the already complex regulatory network that governs exoenzyme production in $E$. carotovora, we looked at the involvement of CRP, KdgR and the bacterial pheromone, OHHL, on the expression of rexZ. It was evident from the in vitro DNA-binding assays that cAMP-CRP bound strongly to the rexZ promoter region, indicating that $\operatorname{Rex} Z$ is catabolite repressed. Additional supporting evidence for this notion came from in vivo quantification of the RexZ protein in the presence and absence of glucose. Therefore, in E. carotovora, there appears to be a hierarchical regulatory cascade controlling degradative exoenzyme synthesis which involves a global cellular regulator (CRP) and a virulence-associated regulator (RexZ). A similar system of control was recently reported in Pseudomonas aeruginosa, where Vfr, a CRP homologue, controls the expression of the LasR activator which is involved in quorum sensing and expression of virulence factor genes (protease and exotoxin A) (Albus et al., 1997). Such a cascade can allow a rapid up- and downregulation of the genes controlling the virulence functions in these bacteria in response to change in environmental conditions.

Distinct from the cAMP-CRP binding site, KdgR ( $E$. chrysanthemi) bound to a site upstream of the rexZ promoter at a position which would not interfere with the binding of RNA polymerase. However, it was formally possible that, because the binding sites of $\mathrm{KdgR}$ and cAMP-CRP overlapped, KdgR could indirectly modulate rex $Z$ expression by antagonistically binding to this region. This was shown not to be the case, as both KdgR and cAMP-CRP could simultaneously occupy their respective binding sites in the rex $Z$ operator region. Some evidence to support this finding came from in vivo quantification of the RexZ protein, which showed that the amount of RexZ detected remained unchanged in presence of pectic compounds in the growth medium (Fig. 5a). However, we cannot rule out the possibility that KdgR could act as repressor on a secondary rex $Z$ promoter, expression from which would be regulated by different environmental conditions. The cellular amount of RexZ was also shown to be unaffected in E. carotovora strains carrying mutations in the $c a r l$ gene, responsible for the production of the bacterial pheromone OHHL, suggesting that the RexZ activator operates independently of the quorum-sensing system.

Immunoblotting experiments showed that RexZ homologues are widely distributed in the erwinias and revealed that E. carotovora possessed a protein which bound the KdgR-specific antibodies, yet was distinct from RexZ. This observation was consistent with Southern blot experiments revealing different genes for rex $Z$ and $k d g R$ (data not shown). We isolated the $k d g R$ homologues from three strains of $E$. carotovora subsp. carotovora and one strain of E. carotovora subsp. atroseptica. Sequence analysis showed that the $E$. chrysanthemi KdgR protein had an N-terminal extension of 42 amino acids compared with the $E$. carotovora homologues. However, if the DNA upstream of the E. carotovora subsp. carotovora $k d g R$ ORF is artificially translated, in-frame with the predicted ATG start site, then 26 of these predicted amino acids match exactly the corresponding amino acids in the E. chrysanthemi KdgR N-terminus (data not shown). Nevertheless, the E. carotovora subsp. carotovora sequence possesses an in-frame stop codon and lacks a suitable translational start site in this region. This result was taken to suggest that the previously designated translational start codon for the E. chrysanthemi kdgR ORF might be incorrect and that the true start codon was at a position corresponding to that of the Escherichia coli and E. carotovora subsp. carotovora $k d g R$ ORFs. However, immunoblotting experiments suggested that the E. chrysanthemi KdgR protein may well be larger than the E. carotovora protein (Fig. 5b), consistent with the possibility that the KdgR proteins from these related bacteria do differ in the N-terminus, due to the position of their translational start codons.

In light of the possible differences between the KdgR proteins of E. carotovora and E. chrysanthemi and the 
obvious difference in function of RexZ, it was important to determine whether this $E$. carotovora $K \mathrm{dgR}$ protein was functionally similar to the E. chrysanthemi homologue. We demonstrated that partially purified $E$. carotovora $\mathrm{KdgR}$ protein was able to bind specifically to sequences carrying the consensus KdgR-box, and that binding was abolished by the addition of KdgR-specific antibodies and pectin compounds. Thus it would appear that the 'true' $E$. carotovora $\mathrm{KdgR}$ homologue is very similar to that of $E$. chrysanthemi in both sequence and function. However, that the E. carotovora KdgR protein exerts its control on target genes by identical mechanisms to those already established for the $E$. chrysanthemi KdgR protein (Nasser et al., 1997) may require confirmation. Preliminary experiments indicate that the in vitro binding affinities of the E. chrysanthemi $\mathrm{KdgR}$ protein for the E. carotovora pelC, pelD and aepH $(r s m B)$ promoter regions are low (data not shown), which is in agreement with the significant degeneration of the 'KdgR-box' sequence identified in the regulatory regions of $E$. carotovora pel genes versus the $\mathrm{KdgR}$ consensus defined in the E. chrysanthemi system (Nasser et al., 1994; W. Nasser \& G. P. C. Salmond, unpublished results). Given the $\mathrm{N}$-terminal sequence differences of these proteins, these data support the notion that the mechanisms of these closely related proteins may be subtly different. Work is currently in progress to compare directly the activity of the KdgR proteins from E. carotovora and E. chrysanthemi.

We have shown that E. carotovora possesses two previously uncharacterized proteins, both of which belong to the IclR family of transcriptional regulators. These proteins, KdgR and RexZ, represent two new regulatory inputs in the already complex regulatory network that governs virulence in the phytopathogen $E$. carotovora. The presence of multiple positive regulators controlling exoenzyme production in E. carotovora generally contrasts with the situation in E. chrysanthemi, where only two true activators, represented by the CRP and Pir proteins, had been previously discovered (Reverchon et al., 1997; Nomura et al., 1998). However, this study has revealed that E. chrysanthemi expresses a protein homologue of the positively acting regulatory protein $\operatorname{RexZ}$. It would be interesting to discover whether this, as yet uncharacterized, homologue of RexZ also acts in a similar manner in this background. In E. chrysanthemi, synthesis of exoenzymes, particularly of the pectinases, is fundamentally governed by repression mediated by pecS, pecT and kdgR (Reverchon et al., 1991, 1994; Surgey et al., 1996). Analysis of the distribution of these different regulators in bacteria of the genus Erwinia has revealed the presence of pecT/hexA (Castillo \& Reverchon, 1997; Harris et al., 1998), expl/carl (Nasser et al., 1998; Reverchon et al., 1998; Jones et al., 1993; Pirhonen et $a l ., 1993$ ), and rexZ and $k d g R$ homologues (this work) in both E. chrysanthemi and E. carotovora. However, in vivo comparative studies for many of these proteins, such as PecT/HexA and proteins encoded by the quorum-sensing locus, suggest that the mechanism by which they are involved in pel gene expression is different in these two Erwinia species (Nasser et al., 1998; Reverchon et al., 1998; Harris et al., 1998). This is reinforced by the fact that, until this study, all the screening for mutations affecting exoenzyme production, particularly production of Pel, failed to identify a common regulator in both $E$. chrysanthemi and $E$. carotovora. However, this work has shown that, not only is the E. carotovora $\mathrm{KdgR}$ protein highly similar to that of E. chrysanthemi, it is also functionally interchangeable. Therefore, this represents one of the few regulators of exoenzyme production that is both common to and interchangeable between $E$. chrysanthemi and E. carotovora.

\section{NOTE ADDED IN PROOF}

We have recently sequenced the $\mathrm{N}$-terminus of the E. chrysanthemi KdgR protein and confirmed the true translational start to be the methionine at position 43 of the published sequence (and therefore coincident with the start sites of all other KdgR homologues). The relevant GenBank entry, X62072, will be updated accordingly.

\section{ACKNOWLEDGEMENTS}

This work was supported by grants from the BBSRC (no. P06134), CNRS, the DRED and the Actions concertées Coordonnées-Sciences du Vivant 6 from the Ministère de l'Education Nationale, de l'Enseignement Supérieur, de la Recherche et de la Formation Professionnelle. We are indebted to Christiane Nardon, N. Hugouvieux-Cotte-Pattat, G. Condemine, S. Reverchon, A. Castillo and A. Buchet for their help and useful comments.

\section{REFERENCES}

Albus, A., Pesci, E., Runyen-Janecky, L., West, S. \& Iglewski, B. (1997). Vfr controls quorum sensing in Pseudomonas aeruginosa. J Bacteriol 179, 3928-3935.

Andro, T., Chambost, J. P., Kotoujansky, A., Cattaneo, J., Bertheau, Y., Barras, F., van Gijsegem, F. \& Coleno, A. (1984). Mutants of Erwinia chrysanthemi defective in secretion of pectinase and cellulase. J Bacteriol 160, 1199-1203.

Ausubel, F. M., Brent, R., Kingston, R. E., Moore, D. D., Seidman, J. G., Smith, J. A. \& Struhl, K. (1987). Current Protocols in Molecular Biology. New York: Wiley-Interscience.

Barras, F., Vangijsegem, F. \& Chatterjee, A. K. (1994). Extracellular enzymes and pathogenesis of soft-rot Erwinia. Annu Rev Phytopathol 32, 201-234.

Basham, H. G. \& Bateman, D. F. (1975). Relationship of cell death in plant tissue treated with a homogeneous endo-pectate lyase to cell wall degradation. Physiol Plant Pathol 5, 249-262.

Boccara, M., Diolez, A., Rouve, M. \& Kotoujansky, A. (1988). The role of individual pectate lyases of Erwinia chrysanthemi strain 3937 in pathogenicity on Saintpaulia plants. Physiol Mol Plant Pathol 33, 95-104.

Castillo, A. \& Reverchon, S. (1997). Characterisation of the pecT control region from Erwinia chrysanthemi strain 3937. J Bacteriol 179, $4909-4918$. 
Chang, A. \& Cohen, S. (1978). Construction and characterisation of amplifiable multicopy DNA cloning vehicles derived from P154 cryptic miniplasmid. J Bacteriol 134, 1141-1156.

Chatterjee, A., Cui, Y., Liu, Y., Dumenyo, C. K. \& Chatterjee, A. K (1995). Inactivation of $r s m A$ leads to overexpression of extracellular pectinases, cellulases and proteases in Erwinia carotovora subsp. carotovora in the absence of the starvation/cell densitysensing signal, N-(3-oxohexanoyl)-L-homoserine lactone. Appl Environ Microbiol 61, 1959-1967.

Collmer, A. \& Keen, N. T. (1986). The role of pectic enzymes in plant pathogenesis. Annu Rev Phytopathol 24, 383-409.

Condemine, G. \& Robert-Baudouy, J. (1987). Tn5 insertion in $k d g R$, a regulatory gene of the polygalacturonate pathway in Erwinia chrysanthemi. FEMS Microbiol Lett 42, 39-46.

Condemine, G., Hugouvieux-Cotte-Pattat, N. \& Robert-Baudouy, J. (1986). Isolation of Erwinia chrysanthemi kduD mutants altered in pectin degradation. J Bacteriol 165, 937-941.

Cui, Y., Chatterjee, A., Liu, Y., Dumenyo, C. K. \& Chatterjee, A. K. (1995). Identification of a global repressor gene, rsmA, of Erwinia carotovora subsp. carotovora that controls extracellular enzymes, $\mathrm{N}$-(3-oxohexanoyl)-L-homoserine lactone, and pathogenicity in soft-rotting Erwinia spp. J Bacteriol 177, 5108-5115.

Hanahan, D. (1983). Studies on transformation of Escherichia coli with plasmids. J Mol Biol 166, 557-580.

Hankin, L. \& Angnostakis, S. L. (1975). The use of solid media for the detection of enzyme production by fungi. Mycologia 67, $597-607$.

Harris, S. J., Shih, Y., Bentley, S. D. \& Salmond, G. P. C. (1998). The bexA gene of Erwinia carotovora encodes a LysR homologue and regulates motility and the expression of multiple virulence determinants. Mol Microbiol 28, 705-717.

Harrison, S. C. \& Aggarwal, A. K. (1990). DNA recognition by proteins with the helix-turn-helix motif. Annu Rev Biochem 59, 933-969.

Herrero, M., De Lorenzo, V. \& Timmis, K. (1990). Transposon vectors containing non-antibiotic resistance selection markers for cloning and stable chromosomal insertion of foreign genes in gram-negative bacteria. J Bacteriol 172, 6557-6567.

Hinton, J. \& Salmond, G. (1987). Use of TnphoA to enrich for extracellular mutants of Erwinia carotovora subsp. carotovora. Mol Microbiol 1, 381-386.

Hinton, J., Perombelon, M. \& Salmond, G. (1985). Efficient transformation of Erwinia carotovora subsp. carotovora and $E$. carotovora subsp. atroseptica. J Bacteriol 161, 786-788.

Hinton, J. C. D., Sidebotham, J. M., Hyman, L. J., Perombelon, M. C. M. \& Salmond, G. P. C. (1989). Isolation and characterisation of transposon-induced mutants of Erwinia carotovora subsp. atroseptica exhibiting reduced virulence. Mol Gen Genet 217, 141-148.

Hugouvieux-Cotte-Pattat, N. \& Robert-Baudouy, J. (1987). Hexuronate catabolism in Erwinia chrysanthemi. J Bacteriol 169, 1223-1231.

Hugouvieux-Cotte-Pattat, N., Condemine, G., Nasser, W. \& Reverchon, S. (1996). Regulation of pectinolysis in Erwinia chrysanthemi. Annu Rev Microbiol 50, 213-257.

James, V. \& Hugouvieux-Cotte-Pattat, N. (1996). Regulatory systems modulating the transcription of the pectinase genes of Erwinia chrysanthemi are conserved in Escherichia coli. Microbiology 142, 2613-2619.

Jones, S., Yu, B., Bainton, N. J. \& 11 other authors (1993). The lux autoinducer regulates the production of exoenzyme virulence determinants in Erwinia carotovora and Pseudomonas aeruginosa. EMBO J 12, 2477-2482.

Kaniga, K., Delor, I. \& Cornelis, G. (1991). A wide-host-range suicide vector for improving reverse genetics in Gram-negative bacteria : inactivation of the blaA gene of Yersinia enterocolitica. Gene 109, 137-141.

Kolb, A., Busby, S., Buc, H., Garges, S. \& Adhya, S. (1993). Transcriptional regulation by cAMP and its receptor protein. Annu Rev Biochem 62, 749-795.

Kotoujansky, A., Lemattre, M. \& Boistard, F. (1982). Utilisation of thermosensitive episome bearing transposon $\operatorname{Tn} 10$ to isolate $\mathrm{HFr}$ donor strain of Erwinia carotovora subsp. chrysanthemi. J Bacteriol 150, 122-131.

Laurent, F., Kotoujansky, A., Labesse, G. \& Bertheau, Y. (1993). Characterisation and overexpression of the pem gene encoding pectin methylesterase of Erwinia chrysanthemi strain 3937. Gene 131, 17-25.

Liu, Y., Murata, H., Chatterjee, A. \& Chatterjee, A. K. (1993). Characterisation of a novel regulatory gene aepA that controls extracellular enzyme production in the phytopathogenic bacterium E. carotovora subsp. carotovora. Mol Plant-Microbe Interact 6, 299-308.

Liu, Y., Cui, Y., Mukherjee, A. \& Chatterjee, A. K. (1998). Characterisation of a novel RNA regulator of Erwinia carotovora subsp. carotovora that controls production of extracellular enzymes and secondary metabolites. Mol Microbiol 29, 219-234.

McGowan, S., Sebaihia, M., Jones, S. \& 7 other authors (1995). Carbapenem antibiotic production in Erwinia carotovora is regulated by CarR, a homologue of the LuxR transcriptional activator. Microbiology 141, 541-550.

McGowan, S., Sebaihia, M., Porter, L., Stewart, G., Williams, P., Bycroft, B. \& Salmond, G. (1996). Analysis of bacterial carbapenem antibiotic production genes reveals a novel $\beta$-lactam biosynthesis pathway. Mol Microbiol 22, 415-426.

McGowan, S., Sebaihia, M., O'Leary, S., Hardie, K. H., Williams, P., Stewart, G., Bycroft, B. \& Salmond, G. (1997). Analysis of the carbapenem gene cluster of Erwinia carotovora: definition of the antibiotic biosynthetic genes and evidence for a novel $\beta$-lactam resistance mechanism. Mol Microbiol 26, 545-556.

Miller, J. H. (1972). Experiment in Molecular Genetics. New York: Cold Spring Harbor Laboratory.

Moran, F., Nasuno, S. \& Starr, M. P. (1968). Oligogalacturonide trans-eliminase of Erwinia carotovora. Arch Biochem Biophys 125, 734-741.

Murata, H., McEvoy, J. L., Chatterjee, A., Collmer, A. \& Chatterjee, A. K. (1991). Molecular cloning of an aepA gene that activates production of extracellular pectolytic, cellulolytic, and proteolytic enzymes in Erwinia carotovora subsp. carotovora. Mol Plant-Microbe Interact 4, 239-246.

Murata, H., Chatterjee, A., Liu, Y. \& Chatterjee, A. K. (1994). Regulation of the production of extracellular pectinase, cellulase, and protease in the soft rot bacterium Erwinia carotovora subsp. carotovora: evidence that aepH of E. carotovora subsp. carotovora 71 activates gene expression in E. carotovora subsp. carotovora, E. carotovora subsp. atroseptica, and Escherichia coli. Appl Environ Microbiol 60, 3150-3159.

Nasser, W., Condemine, G., Plantier, R., Anker, D. \& RobertBaudouy, J. (1991). Inducing properties of analogues of 2-keto-3deoxygluconate on the expression of pectinase genes of Erwinia chrysanthemi. FEMS Microbiol Lett 81, 73-78.

Nasser, W., Reverchon, S. \& Robert-Baudouy, J. (1992). Purification and functional characterisation of the KdgR protein, a 
major repressor of pectinolysis genes of Erwinia chrysanthemi. Mol Microbiol 6, 257-265.

Nasser, W., Reverchon, S., Condemine, G. \& Robert-Baudouy, J. (1994). Specific interactions of Erwinia chrysanthemi $\mathrm{KdgR}$ repressor with different operators of genes involved in pectinolysis. J Mol Biol 236, 427-440.

Nasser, W., Robert-Baudouy, J. \& Reverchon, S. (1997). Antagonistic effect of CRP and KdgR in the transcription control of the Erwinia chrysanthemi pectinolysis genes. Mol Microbiol 26, 1071-1082.

Nasser, W., Bouillant, M. L., Salmond, G. \& Reverchon, S. (1998).

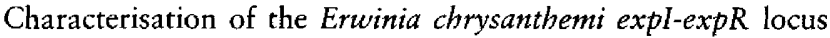
directing the synthesis of two $\mathrm{N}$-acyl-homoserine lactone signal molecules. Mol Microbiol 29, 1391-1405.

Nomura, K., Nasser, W., Kawagishi, H. \& Tsuyumu, S. (1998). The pir gene of Erwinia chrysanthemi EC16 regulates hyperinduction of pectate lyase virulence genes in response to plant signals. Proc Natl Acad Sci USA 95, 14034-14039.

Pirhonen, M., Saarilahti, H., Karlsson, M. B. \& Palva, E. T. (1991). Identification of pathogenicity determinants of Erwinia carotovora subsp. carotovora by transposon mutagenesis. Mol Plant-Microbe Interact 4, 276-283.

Pirhonen, M., Flego, D., Heikinheimo, R. \& Palva, E. T. (1993). A small diffusible signal molecule is responsible for the global control of virulence and exoenzyme production in plant pathogen Erwinia carotovora. EMBO J 12, 2467-2476.

Praillet, T., Nasser, W., Robert-Baudouy, J. \& Reverchon, S. (1996). Purification and functional characterisation of PecS: a regulator of virulence factor synthesis in Erwinia chrysanthemi. Mol Microbiol 20, 391-402.

Reverchon, S. \& Robert-Baudouy, J. (1987). Molecular cloning of Erwinia chrysanthemi oligogalacturonate lyase gene involved in pectin degradation. Gene 55, 125-133.

Reverchon, S., Nasser, W. \& Robert-Baudouy, J. (1989). Nucleotide sequence of the Erwinia chrysanthemi ogl and pelE genes, negatively regulated by the $k d g R$ product. Gene $85,125-134$.

Reverchon, S., Nasser, W. \& Robert-Baudouy, J. (1991). Characterisation of $k d g R$, a gene of Erwinia chrysanthemi that regulates pectin degradation. Mol Microbiol 5, 2203-2216.

Reverchon, S., Nasser, W. \& Robert-Baudouy, J. (1994). pecS: a locus controlling pectinase, cellulase and blue pigment production in Erwinia chrysanthemi. Mol Microbiol 11, 1127-1139.

Reverchon, S., Expert, D., Robert-Baudouy, J. \& Nasser, W. (1997). The cyclic AMP receptor protein is the main activator of the pectinolysis genes in Erwinia chrysanthemi. J Bacteriol 179, 3500-3508.

Reverchon, S., Bouillant, M. L., Salmond, G. \& Nasser, W. (1998). Integration of the quorum-sensing system in the regulatory networks controlling virulence factor synthesis in Erwinia chrysanthemi. Mol Microbiol 29, 1407-1418.

Russel, M. \& Model, P. (1984). Replacement of the fip gene of Escherichia coli by an inactive gene cloned on a plasmid. J Bacteriol 159, 1034-1039.
Sakakibara, H., Watanabe, M., Hase, T. \& Sugiyama, T. (1991). Molecular cloning and characterisation of complementary DNA encoding for ferredoxin-dependent glutamate synthetase in maize leaf. J Biol Chem 226, 2028-2035.

Salmond, G. P. C., Golby, P. \& Jones, S. (1994). Global regulation of Erwinia carotovora virulence factor production. In Advances in Molecular Genetics of Plant-Microbe Interactions, vol. 3, pp. 13-20. Edited by M. J. Daniels, J. A. Downie \& A. E. Osbourn. Dordrecht: Kluwer.

Salmond, G. P. C., Bycroft, B. W., Stewart, G. S. A. B. \& Williams, P. (1995). The bacterial 'enigma': cracking the code of cell-cell communication. Mol Microbiol 16, 615-624.

Sanger, F., Nicklen, S. \& Coulson, A. R. (1977). DNA sequencing with chain-terminating inhibitors. Proc Natl Acad Sci USA 74, 5463-5467.

Shevchik, V. E., Condemine, G., Hugouvieux-Cotte-Pattat, N. \& Robert-Baudouy, J. (1996). Characterisation of pectin methylesterase B, an outer membrane lipoprotein of Erwinia chrysanthemi 3937. Mol Microbiol 19, 455-466.

Smith, C. P. \& Chater, K. (1988). Structure and regulation of controlling sequences for the Streptomyces coelicolor glycerol operon. $J$ Mol Biol 204, 569-580.

Sofia, H. J., Burland, V., Daniels, D. L., Plunkett, G. \& Blattner, F. R. (1994). Analysis of the Escherichia coli genome. .5. DNAsequence of the region from 76.0 -minutes to 81.5 -minutes. Nucleic Acids Res 22, 2576-2586.

Sunnarborg, A., Klump, D., Chung, T. \& LaPorte, D. C. (1990). Regulation of the glyoxylate bypass operon: cloning and characterisation of iclR. J Bacteriol 172, 2642-2649.

Surgey, N., Robert-Baudouy, J. \& Condemine, G. (1996). The Erwinia chrysanthemi pecT gene regulates pectinase gene expression. J Bacteriol 178, 1593-1599.

Tabor, S. \& Richardson, C. (1985). A bacteriophage T7 RNA polymerase/promoter system for controlled exclusive expression of specific genes. Proc Natl Acad Sci USA 82, 1074-1078.

Thomson, N. R., Cox, A., Bycroft, B. W., Stewart, G. S. A. B., Williams, P. \& Salmond, G. P. C. (1997). The Rap and Hor proteins of Erwinia, Serratia and Yersinia: a novel subgroup in a growing superfamily of proteins regulating diverse physiological processes in bacterial pathogens. Mol Microbiol 26, 531-544.

Van Gijsegem, F. \& Toussaint, A. (1982). Chromosome transfer and R-prime formation by an RP4::mini-Mu derivative in Escherichia coli, Salmonella typhimurium, Klebsiella pneumoniae and Proteus mirabilis. Plasmid 7, 30-44.

Yanisch-Perron, C., Vieira, J. \& Messing, J. (1985). Improved M13 phage cloning vectors and host strains: nucleotide sequences of the M13mp18 and pUC19 vectors. Gene 33, 103-119.

Received 8 December 1998; revised 26 March 1999; accepted 6 April 1999. 